\title{
Effects of PEG-6000 Induced Water Deficit Stress on Physiological and Biochemical Characteristics of Pearl Millet Seedlings
}

\author{
Shubham B. Deshmukh" and M.K. Mandavia \\ Department of Biochemistry, College of Agriculture, Junagadh Agricultural University, \\ Junagadh-362 001, India \\ *Corresponding author
}

\author{
A B S T R A C T
}

K e y w o r d s
Pearl millet, Water
relations, PEG-
6000, Membrane
stability, Osmotic
adjustment.
Article Info
Accepted:
14 September 2017
Available Online:
10 October 2017

Ten pearl millet genotypes differing in their drought sensitivity were evaluated at seedling stage for drought tolerance through physiological and biochemical criteria to understand the beneath mechanism of drought tolerance. The main purpose of this work was to screen the highly tolerant and susceptible genotypes under PEG-6000 induced drought stress. A laboratory experiment was conducted in a randomized complete block design, drought stress was induced in seedling on $15^{\text {th }}$ day of germination by exposing them to different stress levels i.e. $\mathrm{T}_{1}$ (Control); $\mathrm{T}_{2}(6 \% \mathrm{PEG})$ and $\mathrm{T}_{3}$ (8\% PEG) for 6 hours. A comparative analysis of different pearl millet genotypes revealed that the tolerant genotypes was superior over the susceptible genotypes in terms of leaf water relations (RWC), membrane stability (MSI), osmolytes accumulation and lipid peroxidation (MDA). Simple correlation coefficient analysis revealed significant positive association of RWC at $0.01 \%$ level with MSI and GB. While the proline and MDA were significantly and negatively correlated with RWC. On the basis of these results we have chosen J-2549 as susceptible and J-2454 as tolerant genotype for drought stress. This analysis clearly showed that maintenance of higher membrane stability, plant water status and accumulation of compatible solutes play an important role in plants tolerance under drought conditions.

\section{Introduction}

Pearl millet (Pennisetum glaucum L.) is the most widely grown minor cereal crop worldwide among the millets. It is recognized as an important food and forage crop in many countries of Asia and Africa. As pearl millet can withstand drought and high temperature stress during either the vegetative or reproductive phases of its growth, hence is mostly preferred for arid and semiarid regions which experience frequent periods of dry weather. Currently, drought is one of the most important limiting factors for crop production and becoming an increasingly severe problem in many regions of the world (Aslam et al., 2006). Water stress affects almost every developmental stage of the plant.

However, damaging effects of this stress was more noted when it coincided with various growth stages such as germination; vegetative and flowering (Khayatnezhad et al., 2010). In order to combat its adverse effects, it is essential to develop water-deficit stress tolerant genotypes. To achieve that, a better understanding of the stress induced responses and the interrelationships of physiological and 
biochemical traits in drought tolerant crop such as pearl millet can prove to be very useful. Many reports have indicated that, selection of drought stress tolerant plant species/cultivars would have economic and efficient means of utilizing drought-prone areas (Turner, 1997). Elucidating variations and modifications in morpho-physiological traits under different drought stress levels is crucial in improving yield under water limiting conditions.

Plants exhibit several adaptations to survive under stress conditions like reduced leaf area, stomatal closure to prevent the transpirational water loss, decreased stomatal conductance, limited internal $\mathrm{CO}_{2}$ concentration, reduced photosynthesis are very vital.

Plant cells also accumulate solutes to prevent water loss and to re-establish cell turgor. The accumulation of solutes during stress for osmotic adjustment is a general way to stabilize membranes and maintain protein conformation at low leaf water potentials (Reddy et al., 2004).

Several physiological and biochemical characteristics have been reported as being reliable indicators for the selection of genotypes possessing drought tolerance. These characteristics include higher relative water content, membrane stability and osmolytes accumulation.

The success of these approaches requires evidence that the drought tolerance of cultivars tested under laboratory and greenhouse conditions also reflects this character under field conditions (Sammons et al., 1978). The aim of this study was to investigate the effects of osmotic stress generated by different levels of PEG-6000 on seedling stage of pearl millet genotypes. The primary objective of the present study was to screen out the most tolerant and most sensitive pearl millet genotypes under artificially induced PEG drought stress.

\section{Materials and Methods}

\section{Experimental materials}

Seeds of ten pearl millet genotypes with different sensitivity to water-deficit stress i.e. (J-2549，J-2290， J-2454，J-2467，J-2340, ICMB-04111, ICMB-94555, ICMB-95222, ICMB-95444, and ICMB-96222) were obtained from Pearl millet Research Station, Jamnagar, Junagadh Agricultural University, Junagadh.

\section{Experimental details}

The experiment was laid out in randomized complete block design with two factors (genotypes and water stress level) and three replications. Twenty seedlings of each genotype were grown in a plastic bag $(6 \times 6$ $\mathrm{cm})$.

The plastic bags were protected by net covering and were watered periodically. There were three treatments comprising $\mathrm{T}_{1}$ : (control i.e. no PEG); $\mathrm{T}_{2}$ (6\% PEG); $\mathrm{T}_{3}$ : $(8 \%$ PEG). Seedlings were completely emerged 7 days after sowing. After the 15 DAG, the plastic bags were cut and were flooded with water and 20 seedlings with uniform vigor and height were pulled gently without damaging the roots. The excess soil attached to the roots was washed off with tap water. The seedlings were then placed in $150 \mathrm{ml}$ distilled water $\left(\mathrm{T}_{1}\right.$ : control) in a $250 \mathrm{ml}$ beaker, the stressed treatments $\left(\mathrm{T}_{2}\right.$ and $\left.\mathrm{T}_{3}\right)$ seedlings were kept similarly in $6 \%$ and $8 \%$ PEG solution respectively for 6 hours. At the end of 6 hours the physiological and biochemical parameters were analyzed in three replicates from the leaves randomly collected from each treatment. 


\section{Physiological parameters}

\section{Relative water content}

The method described by Smart and Bingham, (1974) was used for the determination of relative water content of pearl millet genotypes. One gram of fresh leaf samples of pearl millet genotypes were transferred in a Petri dish filled with at least $15-20 \mathrm{ml}$ distilled water so that leaves remain submerged for four hours. Then the leaves were taken out, dried by blotting paper and weighed i.e. turgid weight. After that, turgid leaf samples were kept in oven at $80^{\circ} \mathrm{C}$ overnight and weighed until constant weight was obtained. RWC was calculated using the following formula: RWC $\%=$ (FWDW)/(TW-DW) X 100.

\section{Membrane stability index (MSI)}

Membrane stability index was determined by using the method of Blum and Ebercon, (1981). For determination of membrane stability index of pearl millet genotypes, one $\mathrm{g}$ of fresh leaf tissues were taken and placed in sugar tubes containing $30 \mathrm{ml}$ of distilled water. They were kept in hot water bath at $40^{\circ} \mathrm{C}$ for 30 minutes. After 30 minutes samples were cooled to room temperature and electrical conductivity (EC) was recorded (C1). Then the tubes were kept in boiling water bath at $100^{\circ} \mathrm{C}$ for 10 minutes. After cooling, again electrical conductivity was measured (C2). Membrane stability index was calculated by using the following formula: MSI $\%=(1-\mathrm{C} 1 / \mathrm{C} 2) \times 100$

\section{Oxidative stress parameters}

\section{Determination of Lipid Peroxidation}

Lipid peroxidation (MDA) was measured as the amount of thiobarbituric acid reactive substances (TBARS) determined by the thiobarbituric acid (TBA) reaction (Heath and Packer, 1968). Leaves were homogenized in 5 $\mathrm{ml}$ of $0.1 \%$ thrichloroacetic acid (TCA). The homogenates were centrifuged at $8,000 \mathrm{rpm}$ for 15 minutes and supernatant was collected. To the $1 \mathrm{ml}$ of the aliquot, $4 \mathrm{ml}$ of $0.5 \%(\mathrm{w} / \mathrm{v})$ TBA in $20 \%$ TCA was added. The mixture was heated at $95^{\circ} \mathrm{C}$ for 30 minutes and then quickly cooled in ice bath. The contents were centrifuged at $10000 \mathrm{rpm}$ for 10 minutes and the absorbance of the supernatant was measured at $532 \mathrm{~nm}$. The concentration of TBARS was calculated using an extinction coefficient of $155 \mathrm{mmol}^{-1} \mathrm{~cm}^{-1}$.

\section{Osmoprotectant}

\section{Proline}

The proline content in leaves of pearl millet genotypes was analyzed according to the method suggested by the Bates et al., (1973). The fresh leaves $(0.5 \mathrm{~g})$ were homogenized in $5 \mathrm{ml}$ of 3\% sulphosalicylic acid using mortar and pestle. The homogenate was centrifuged at $8,000 \mathrm{rpm}$ for 10 minutes and clear supernatant was collected in fresh Eppendorf tube. To $1 \mathrm{ml}$ of the supernatant, $2 \mathrm{ml}$ of acid ninhydrin (containing $1.25 \mathrm{gm}$ ninhydrin, 30 $\mathrm{ml}$ of glacial acetic acid and $8 \mathrm{ml}$ of phosphoric acid in $12 \mathrm{ml}$ distilled water) and $2 \mathrm{ml}$ glacial acetic acid were added. The mixture was kept in boiling water bath for 1 $\mathrm{hr}$ and then cooled. Four $\mathrm{ml}$ of toluene was added and gently mixed with vortex mixer. The toluene layer was separated and reading taken at $520 \mathrm{~nm}$ using 1-proline as standard in the concentrations of 5-25 $\mu \mathrm{g}$.

\section{Glycine betaine}

Glycine betaine was estimated from dried leaf powder as per the method given by the Grieve and Grattan, (1983). Finely ground dry plant material $(0.5 \mathrm{~g})$ was mechanically shaken with $20 \mathrm{ml}$ of demonized water for $16 \mathrm{~h}$ at 
$25^{\circ} \mathrm{C}$. The samples were then filtered and the filtrate was stored in freezer until analysis. Thawed extracts were diluted 1:1 with $2 \mathrm{~N}$ sulphuric acid. Aliquot $(0.5 \mathrm{ml})$ was measured into test tube and cooled in ice for $1 \mathrm{hr}$. Then $0.2 \mathrm{ml}$ of cold potassium iodide-iodine reagent [Iodine $(15.7 \mathrm{~g})$ and potassium iodide $(20 \mathrm{~g})$ were dissolved in $100 \mathrm{ml}$ of water and kept in fridge at $4^{\circ} \mathrm{C}$ ] was added and the mixture was gently mixed with vortex mixture. The samples were stored at $0-4^{\circ} \mathrm{C}$ for $16 \mathrm{~h}$. After the expiring of the period, samples were transferred to centrifuge tubes and then centrifuged at $10,000 \mathrm{~g}$ for 15 minutes at $0^{\circ} \mathrm{C}$. The supernatant was carefully aspirated with $1 \mathrm{ml}$ micropipette. The periodite crystals were dissolved in $9 \mathrm{ml}$ of 1, 2-dichloroethane. Vigorous vortex mixing was done to effect complete solubility in developing solvent. After 2.0-2.5 h the absorbance was measured at $365 \mathrm{~nm}$. Glycine betaine standards of were prepared in $2 \mathrm{~N}$ sulphuric acid.

\section{Statistical analysis}

The experimental data was laid out in twofactor (genotype, treatment) factorial arrangement under a completely randomized block design. The data was analyzed using OPSTAT software, Statistical package for agricultural workers (http://hau.ernet.in/about/ opstat.php). Pearson correlation coefficients for all the parameters were carried out using SPSS 16.0 version.

\section{Results and Discussion}

\section{Relative water content}

Relative water content strongly reflects the balance between water supply to the leaf and transpiration. RWC decreased significantly while the severity of PEG stress level increased which leading to lower plant water status in pearl millet genotypes. Among all the genotype the J-2454 showed highest RWC at both PEG treatment followed by the genotype J-2467 and J-2340 compared to their respective control $\left(\mathrm{T}_{1}\right)$, suggesting their role in relatively higher ability to avoid tissue dehydration.

Genotypes which maintain adequate leaf RWC under stress condition can be in generally considered as drought tolerant which is suitable for dry regions. On the contrary, susceptible genotypes were unable to maintain the higher RWC to same extent as the tolerant genotype did. The lowest RWC was found in the genotype J-2549 (67.17\% and $60.77 \%$ ); which was followed by the genotype J-2290 (74.29\% and $63.73 \%$ ) during $\mathrm{T}_{2}$ and $\mathrm{T}_{3}$ PEG stress treatment respectively; compared to their respective control $\left(\mathrm{T}_{1}\right)$ (Table 1). Present results are in agreement with the various reports on pearl millet who reported that RWC was reduced during the water-deficit stress; however the reduction was more rapid in the susceptible genotype than those in tolerant (Vijayalakshmi et al., 2012 and Addisie and Yamane, 2011). From our present results we can conclude that J2454 is drought tolerant and found more suitable for cultivation in low rainfall regions; while the genotype J-2549 found the most susceptible for drought stress. Our results have also confirmed that measuring RWC is a potential tool for screening genotype under various degrees of water stress.

\section{Membrane stability index}

Membrane stability is a widely used criterion to assess crop drought tolerance, since water stress caused by water loss from plant tissues seriously impairs both membrane structure and function (Buchanan et al., 2002). There was no significant difference between the genotypes in terms of MSI in well watered control $\left(\mathrm{T}_{1}\right)$; in contrast there was sharp decline in MSI, while the severity of PEG induced stress increased; however a significantly lower reduction was recorded in the tolerant genotypes. Genotypes which 
maintain higher MSI can be in generally considered as drought tolerant (Addisie and Yemane, 2011). The maximum value of MSI was observed in control treatment, while the least were recorded in PEG treatments. Among the genotypes, highest MSI during the PEG drought stress was recorded in J-2454 $(80.40 \%$ and $78.71 \%$ ) followed by $\mathrm{J}-2467$ (72.41\% and $69.27 \%)$ genotype while the lowest MSI was observed in J-2549 (61.47\% and $65.98 \%$ ) which is followed by $\mathrm{J}-2290$ (69.27\% and $64.60 \%$ ) genotype. (Table 2) Our results are in agreement with the findings of Sairam and Shrivastava, (2001) who reported that during stress there was a decrease in MSI irrespective of the genotypes. Geravandi et al., (2011) demonstrated that drought tolerant genotypes contained higher MSI as compared to drought sensitive genotypes. From present results we can conclude that genotype J-2454 is less affected by the drought stress and found more suitable for cultivation in low rainfall regions; our results has also confirmed that measuring MSI can be used as indicators of stress induced damages at the cellular level in pearl millet genotypes.

\section{Lipid peroxidation (MDA)}

The cell membrane integrity has been widely used as criterion to differentiate between stress tolerant and susceptible genotypes and sometimes this plants capacity to avoid membrane damage has been directly correlated with abiotic stress tolerance (Gill and Tuteja, 2010). Water deficit stress led to an increased membrane disruption, reflected by their higher MDA content. With the increment in PEG concentration the MDA content was increased significantly in all genotypes.

The genotype J-2549 showed the highest rise in MDA content from (240.68 and 260.58 $\mu$ mol.g $\left.{ }^{-1} \mathrm{Fw}\right)$ followed by ICMB-04111 (223.13 and $234.09 \mu \mathrm{mol} . \mathrm{g}^{-1} \mathrm{Fw}$ ) and J-2290
(212.05 and $246.94 \mu$ mol.g ${ }^{-1} \mathrm{Fw}$ ) during $\mathrm{T}_{2}$ and $\mathrm{T}_{3}$ PEG stress treatments respectively. The above findings are supported by Moussa et al., (2008) and Vijayalakshmi et al., (2012) who stated that MDA level induced in susceptible genotypes compared to the tolerant one. The lowest rise in MDA content was observed in the genotype J-2454 (167.83 and $\left.172.21 \mu \mathrm{mol} . \mathrm{g}^{-1} \mathrm{Fw}\right)$ followed by $\mathrm{J}-2467$ (171.93 and $175.01 \mu \mathrm{mol} . \mathrm{g}^{-1} \mathrm{Fw}$ ) during PEG $\mathrm{T}_{2}$ and $\mathrm{T}_{3}$ PEG stress treatments (Table 3). In the present study, the MDA content significantly increased from $\left(\mathrm{T}_{1}\right.$ - control to $\mathrm{T}_{3}-8 \%$ PEG) but the increment in susceptible genotypes is higher than the tolerant genotypes. These results are consistent with the findings of Lata et al., (2010) who reported that the dehydration tolerant genotypes showed considerably lower levels of lipid peroxidation (MDA) as compared with dehydration sensitive genotypes, indicating its better cell membrane integrity in tolerant genotypes. Similar observation are made by the Moussa et al., 2008 and Chugh et al., 2011 who suggested that the MDA content in sensitive genotypes both under non stress and water stress condition was higher as compared to the tolerant genotypes.

\section{Proline content}

The proline content accumulates at very high concentration during the different PEG stress treatments. The proline content increased significantly in the pearl millet genotypes with increasing PEG concentration. The highest proline content was observed in the genotype J-2454 (145.41 and $178.31 \mu \mathrm{g}^{-\mathrm{g}^{-1}}$ $\mathrm{Fw})$ which was further followed by genotype $\mathrm{J}-2340$ at (135.12 and $\left.164.33 \mu \mathrm{g} \cdot \mathrm{g}^{-1} \mathrm{FW}\right)$ and ICMB-95222 (131.56 and $\left.148.48 \mu \mathrm{g} . \mathrm{g}^{-1} \mathrm{Fw}\right)$ whereas, the lowest content was observed in the genotype J-2549 at (99.61 and 108.58 $\left.\mu \mathrm{g} \cdot \mathrm{g}^{-1} \mathrm{Fw}\right)$ followed by genotype J-2290 $\left(118.37\right.$ and $\left.128.19 \mu \mathrm{g} . \mathrm{g}^{-1} \mathrm{FW}\right)$ during the $\mathrm{T}_{2}$ $\left(6 \%\right.$ PEG) and $\mathrm{T}_{3}(8 \%$ PEG) treatment respectively (Table 4$)$. 
Table.1 Effects of PEG induced water deficit stress on relative water content (\%) in leaves of 15 days old seedlings of pearl millet genotypes

\begin{tabular}{|c|c|c|c|}
\hline Genotypes & Control $\left(\mathrm{T}_{1}\right)$ & $6 \%$ PEG $\left(\mathrm{T}_{2}\right)$ & $8 \%$ PEG $\left(T_{3}\right)$ \\
\hline $\mathrm{J}-2467$ & $81.35 \pm 0.134^{b}$ & $78.53 \pm 0.248^{\mathrm{ab}}$ & $75.75 \pm 0.262^{a b}$ \\
\hline J-2454 & $87.09 \pm 0.005^{\mathrm{a}}$ & $81.14 \pm 0.042^{\mathrm{a}}$ & $78.09 \pm 0.051^{\mathrm{a}}$ \\
\hline$J-2340$ & $80.34 \pm 0.071^{b}$ & $76.92 \pm 0.120^{\mathrm{abc}}$ & $75.94 \pm 0.148^{\mathrm{ab}}$ \\
\hline ICMB-95444 & $82.97 \pm 0.246^{\mathrm{ab}}$ & $77.08 \pm 0.306^{\mathrm{abc}}$ & $74.94 \pm 0.511^{\mathrm{ab}}$ \\
\hline ICMB-95222 & $82.51 \pm 0.231^{\mathrm{ab}}$ & $76.55 \pm 0.172^{a b c}$ & $73.68 \pm 0.159^{\mathrm{abc}}$ \\
\hline ICMB-94555 & $79.13 \pm 0.171^{b c}$ & $71.40 \pm 0.244^{\mathrm{cd}}$ & $69.17 \pm 0.180^{c}$ \\
\hline ICMB-96222 & $79.30 \pm 0.215^{b c}$ & $74.77 \pm 0.310^{\mathrm{bc}}$ & $73.19 \pm 0.071^{\mathrm{abc}}$ \\
\hline ICMB-04111 & $77.97 \pm 0.353^{b c}$ & $74.18 \pm 0.233^{b c}$ & $71.33 \pm 0.230^{\mathrm{bc}}$ \\
\hline J-2549 & $73.41 \pm 0.164^{c}$ & $67.17 \pm 0.027^{\mathrm{d}}$ & $60.77 \pm 0.164^{\mathrm{d}}$ \\
\hline J-2290 & $78.54 \pm 0.039^{b c}$ & $74.29 \pm 0.180^{\mathrm{bc}}$ & $63.73 \pm 0.043^{\mathrm{d}}$ \\
\hline Effects & & L.S.D. $(\mathrm{P}<0.05)$ & S.Em. \pm \\
\hline Genotype (G) & & 2.10 & 0.74 \\
\hline Treatment (T) & & 1.62 & 0.58 \\
\hline $\mathbf{G} \mathbf{X} \mathbf{T}$ & & 3.63 & 1.29 \\
\hline $\mathrm{CV} \%$ & & & \\
\hline
\end{tabular}

Values are mean of three replications. Value in each column followed by the same letters is not significantly different according to DMRT at $\mathrm{P} \leq 0.05$. Treatments: $\mathrm{T}_{1}$ : Healthy plant kept in distilled water for 6 hours; $\mathrm{T}_{2}$ : Plant keep in 6\% PEG for 6 hours $\mathrm{T}_{3}$ : Plant kept in $8 \%$ PEG for 6 hours.

Table.2 Effect of PEG induced water deficit stress on membrane stability index (\%) in leaves of 15 days old seedlings of pearl millet genotypes

\begin{tabular}{lccc}
\hline Genotype & Control $\left(\mathbf{T}_{\mathbf{1}}\right)$ & 6\% PEG $\left(\mathbf{T}_{\mathbf{2}}\right)$ & $\mathbf{8 \%}$ PEG $\left.\mathbf{T}_{\mathbf{3}}\right)$ \\
\hline J-2467 & $80.60 \pm 0.28 \mathrm{~b}$ & $72.41 \pm 0.16 \mathrm{bc}$ & $69.27 \pm 0.32 \mathrm{~b}$ \\
J-2454 & $88.07 \pm 0.10 \mathrm{a}$ & $80.40 \pm 0.23 \mathrm{a}$ & $78.71 \pm 0.11 \mathrm{a}$ \\
J-2340 & $74.85 \pm 0.46 \mathrm{bc}$ & $71.37 \pm 0.12 \mathrm{bc}$ & $67.15 \pm 0.47 \mathrm{bc}$ \\
ICMB-95444 & $78.88 \pm 0.03 \mathrm{~b}$ & $73.99 \pm 0.13 \mathrm{ab}$ & $65.86 \pm 0.17 \mathrm{bc}$ \\
ICMB-95222 & $80.30 \pm 0.35 \mathrm{~b}$ & $70.74 \pm 0.01 \mathrm{bc}$ & $67.74 \pm 0.15 \mathrm{bc}$ \\
ICMB-94555 & $75.23 \pm 0.51 \mathrm{bc}$ & $67.66 \pm 0.20 \mathrm{bc}$ & $63.72 \pm 0.17 \mathrm{bc}$ \\
ICMB-96222 & $77.76 \pm 0.22 \mathrm{~b}$ & $72.56 \pm 0.14 \mathrm{bc}$ & $66.53 \pm 0.21 \mathrm{bc}$ \\
ICMB-04111 & $74.92 \pm 0.12 \mathrm{bc}$ & $70.64 \pm 0.21 \mathrm{bc}$ & $65.12 \pm 0.45 \mathrm{bc}$ \\
J-2549 & $69.50 \pm 0.27 \mathrm{c}$ & $65.98 \pm 0.22 \mathrm{c}$ & $61.47 \pm 0.22 \mathrm{c}$ \\
J-2290 & $75.36 \pm 0.10 \mathrm{bc}$ & $69.27 \pm 0.60 \mathrm{bc}$ & $64.60 \pm 0.22 \mathrm{bc}$ \\
\hline Effects & & L.S.D. $(\mathbf{P}<\mathbf{0 . 0 5})$ & S.Em. \pm \\
\hline Genotype $(\mathbf{G})$ & & 2.70 & 0.96 \\
Treatment $(\mathbf{T})$ & & 2.09 & 0.74 \\
G X T & & 4.67 & 1.66 \\
CV\% & & & 8.82 \\
\hline Va & & & \\
\hline
\end{tabular}

Values are mean of three replications. Value in each column followed by the same letters is not significantly different according to DMRT at $\mathrm{P} \leq 0.05$. Treatments: $\mathrm{T}_{1}$ : Healthy plant kept in distilled water for 6 hours; $\mathrm{T}_{2}$ : Plant keep in 6\% PEG for 6 hours $\mathrm{T}_{3}$ : Plant kept in $8 \%$ PEG for 6 hours. 
Table.3 Effect of PEG induced water deficit stress on malondialdehyde ( $\mu$ mol. $\mathrm{g}^{-1} \mathrm{Fw}$ ) in leaves of 15 days old pearl millet seedlings

\begin{tabular}{lccc}
\hline Genotypes & Control $\left(\mathbf{T}_{\mathbf{1}}\right)$ & 6\% PEG $\left(\mathbf{T}_{\mathbf{2}}\right)$ & 8\% PEG $\left.\mathbf{T}_{\mathbf{3}}\right)$ \\
\hline J-2467 & $159.84 \pm 1.05 \mathrm{~cd}$ & $171.93 \pm 0.20 \mathrm{de}$ & $175.01 \pm 0.17 \mathrm{f}$ \\
J-2454 & $147.69 \pm 1.03 \mathrm{~d}$ & $167.83 \pm 0.25 \mathrm{e}$ & $172.21 \pm 0.04 \mathrm{f}$ \\
J-2340 & $172.77 \pm 0.13 \mathrm{bcd}$ & $197.87 \pm 0.81 \mathrm{~cd}$ & $227.74 \pm 0.68 \mathrm{bcd}$ \\
ICMB-95444 & $164.70 \pm 0.52 \mathrm{~cd}$ & $171.21 \pm 0.37 \mathrm{e}$ & $218.85 \pm 0.39 \mathrm{cde}$ \\
ICMB-95222 & $160.35 \pm 0.35 \mathrm{~cd}$ & $177.50 \pm 0.68 \mathrm{de}$ & $197.28 \pm 0.17 \mathrm{ef}$ \\
ICMB-94555 & $172.58 \pm 0.07 \mathrm{bcd}$ & $185.10 \pm 0.34 \mathrm{de}$ & $206.69 \pm 0.77 \mathrm{de}$ \\
ICMB-96222 & $193.17 \pm 0.39 \mathrm{ab}$ & $194.66 \pm 0.25 \mathrm{cde}$ & $232.22 \pm 0.19 \mathrm{bc}$ \\
ICMB-04111 & $196.01 \pm 0.31 \mathrm{ab}$ & $223.13 \pm 0.38 \mathrm{ab}$ & $234.09 \pm 0.60 \mathrm{bc}$ \\
J-2549 & $205.69 \pm 0.97 \mathrm{a}$ & $240.68 \pm 0.57 \mathrm{a}$ & $260.58 \pm 0.30 \mathrm{a}$ \\
J-2290 & $182.91 \pm 0.18 \mathrm{abc}$ & $212.05 \pm 0.24 \mathrm{bc}$ & $246.94 \pm 0.16 \mathrm{ab}$ \\
\hline Effects & & L.S.D. (P<0.05) & S.Em. \pm \\
\hline Genotype $(\mathbf{G )}$ & & 9.53 & 3.38 \\
Treatment $(\mathbf{T})$ & & 7.38 & 2.62 \\
G X T & & 16.51 & 5.86 \\
CV\% & & & 7.34 \\
\hline
\end{tabular}

Values are mean of three replications. Value in each column followed by the same letters is not significantly different according to DMRT at $\mathrm{P} \leq 0.05$. Treatments: $\mathrm{T}_{1}$ : Healthy plant kept in distilled water for 6 hours; $\mathrm{T}_{2}$ : Plant keep in 6\% PEG for 6 hours $\mathrm{T}_{3}$ : Plant kept in $8 \%$ PEG for 6 hours.

Table.4 Effect of PEG induced water deficit stress on of proline $\left(\mu \mathrm{g} \cdot \mathrm{g}^{-1} \mathrm{Fw}\right)$ content in leaves of 15 days old pearl millet seedlings

\begin{tabular}{|c|c|c|c|}
\hline Genotypes & Control $\left(\mathrm{T}_{1}\right)$ & $6 \%$ PEG $\left(\mathrm{T}_{2}\right)$ & $8 \%$ PEG $\left(\mathrm{T}_{3}\right)$ \\
\hline J-2467 & $67.19 \pm 1.70 \mathrm{e}$ & $114.33 \pm 1.50 \mathrm{~g}$ & $127.70 \pm 1.08 \mathrm{~g}$ \\
\hline J-2454 & $79.42 \pm 1.50 \mathrm{a}$ & $145.41 \pm 1.50 \mathrm{a}$ & $178.31 \pm 1.11 \mathrm{a}$ \\
\hline $\mathrm{J}-2340$ & $73.53 \pm 1.70 b$ & $135.12 \pm 1.00 \mathrm{~b}$ & $164.33 \pm 1.13 b$ \\
\hline ICMB-95444 & $66.91 \pm 1.42 \mathrm{e}$ & $124.55 \pm 1.30 \mathrm{e}$ & $142.55 \pm 3.10 \mathrm{e}$ \\
\hline ICMB-95222 & $64.19 \pm 1.98 \mathrm{f}$ & $131.56 \pm 1.30 \mathrm{c}$ & $148.48 \pm 1.50 \mathrm{c}$ \\
\hline ICMB-94555 & $58.51 \pm 1.20 \mathrm{~g}$ & $109.63 \pm 1.40 \mathrm{i}$ & $122.39 \pm 1.70 \mathrm{~h}$ \\
\hline ICMB-96222 & $63.41 \pm 1.10 \mathrm{f}$ & $127.66 \pm 1.30 \mathrm{~d}$ & $137.52 \pm 1.60 \mathrm{f}$ \\
\hline ICMB-04111 & $71.61 \pm 1.40 \mathrm{c}$ & $112.47 \pm 1.10 \mathrm{~h}$ & $146.59 \pm 1.60 \mathrm{~d}$ \\
\hline J-2549 & $72.61 \pm 0.80 \mathrm{bc}$ & $99.61 \pm 1.20 \mathrm{j}$ & $108.58 \pm 1.03 \mathrm{i}$ \\
\hline J-2290 & $69.72 \pm 0.12 \mathrm{~d}$ & $118.37 \pm 1.50 \mathrm{f}$ & $128.19 \pm 0.38 \mathrm{~g}$ \\
\hline Effects & & L.S.D. $(\mathrm{P}<\mathbf{0 . 0 5})$ & S.Em. \pm \\
\hline Genotype (G) & & 0.27 & 0.77 \\
\hline Treatment (T) & & 0.15 & 0.42 \\
\hline G X T & & 0.47 & 1.33 \\
\hline CV\% & & \multicolumn{2}{|c|}{7.75} \\
\hline
\end{tabular}

Values are mean of three replications. Value in each column followed by the same letters is not significantly different according to DMRT at $\mathrm{P} \leq 0.05$. Treatments: $\mathrm{T}_{1}$ : Healthy plant kept in distilled water for 6 hours; $\mathrm{T}_{2}$ : Plant keep in 6\% PEG for 6 hours $\mathrm{T}_{3}$ : Plant kept in $8 \%$ PEG for 6 hours. 
Table.5 Effect of PEG induced water deficit stress on glycine betaine $\left(\mu \mathrm{mol} . \mathrm{g}^{-1} \mathrm{Fw}\right)$ content in leaves of 15 days old pearl millet seedlings

\begin{tabular}{lccc}
\hline Genotypes & Control $\left(\mathbf{T}_{\mathbf{1}}\right)$ & 6\% PEG $\left(\mathbf{T}_{\mathbf{2}}\right)$ & $\mathbf{8 \%}$ PEG $\left.\mathbf{( T}_{\mathbf{3}}\right)$ \\
\hline J-2467 & $34.33 \pm 1.20 \mathrm{e}$ & $47.39 \pm 1.21 \mathrm{~d}$ & $54.73 \pm 1.87 \mathrm{~d}$ \\
J-2454 & $48.58 \pm 1.56 \mathrm{a}$ & $61.35 \pm 2.01 \mathrm{a}$ & $72.59 \pm 1.44 \mathrm{a}$ \\
J-2340 & $43.53 \pm 1.04 \mathrm{~b}$ & $53.52 \pm 1.15 \mathrm{~b}$ & $59.39 \pm 1.55 \mathrm{~b}$ \\
ICMB-95444 & $41.50 \pm 2.17 \mathrm{c}$ & $52.41 \pm 1.57 \mathrm{c}$ & $58.43 \pm 2.47 \mathrm{c}$ \\
ICMB-95222 & $38.35 \pm 1.71 \mathrm{~d}$ & $46.50 \pm 1.59 \mathrm{e}$ & $53.33 \pm 1.84 \mathrm{e}$ \\
ICMB-94555 & $34.59 \pm 1.32 \mathrm{e}$ & $41.45 \pm 1.24 \mathrm{f}$ & $47.59 \pm 1.78 \mathrm{f}$ \\
ICMB-96222 & $27.21 \pm 1.62 \mathrm{~h}$ & $32.30 \pm 1.54 \mathrm{I}$ & $38.40 \pm 2.63 \mathrm{i}$ \\
ICMB-04111 & $31.48 \pm 1.28 \mathrm{f}$ & $37.26 \pm 0.90 \mathrm{~g}$ & $46.60 \pm 1.42 \mathrm{~g}$ \\
J-2549 & $23.46 \pm 2.18 \mathrm{i}$ & $27.26 \pm 1.94 \mathrm{j}$ & $34.39 \pm 1.61 \mathrm{j}$ \\
J-2290 & $30.36 \pm 1.22 \mathrm{~g}$ & $36.55 \pm 2.14 \mathrm{~h}$ & $44.53 \pm 2.29 \mathrm{~h}$ \\
\hline Effects & L.S.D. $(\mathbf{P}<\mathbf{0 . 0 5})$ & S.Em. \pm \\
\hline Genotype (G) & & 0.09 & 0.25 \\
Treatment $(\mathbf{T})$ & & 0.05 & 0.14 \\
G X T & & 0.15 & 0.43 \\
CV\% & & & 4.03 \\
\hline
\end{tabular}

Values are mean of three replications. Value in each column followed by the same letters is not significantly different according to DMRT at $\mathrm{P} \leq 0.05$. Treatments: $\mathrm{T}_{1}$ : Healthy plant kept in distilled water for 6 hours; $\mathrm{T}_{2}$ : Plant keep in 6\% PEG for 6 hours $\mathrm{T}_{3}$ : Plant kept in $8 \%$ PEG for 6 hours.

Table.6 Pearson correlation coefficients analysis between studied traits in pearl millet genotypes under drought stress at seedling stage

\begin{tabular}{|c|c|c|c|c|c|}
\hline & RWC & MSI & Proline & GB & MDA \\
\hline RWC & 1.00 & & & & \\
\hline MSI & $0.90^{* *}$ & 1.00 & & & \\
\hline Proline & $-0.35^{*}$ & $-0.45^{* *}$ & 1.00 & & \\
\hline GB & 0.16 & 0.05 & $0.74^{* * *}$ & 1.00 & \\
\hline MDA & $-0.87^{* *}$ & $-0.84^{* *}$ & $0.35^{*}$ & -0.19 & 1.00 \\
\hline
\end{tabular}

$*$ and $* *$ Significant at $\mathrm{P} \leq 0.05$ and 0.01 , respectively $\mathrm{n}=30$

Enhanced level of proline in the leaves of drought stressed plant may be due to the synthesis or breakdown of proline rich protein has been reported by several workers they also suggested that the genotypes with high proline content manifest a high drought tolerance in pearl millet plants (Giancarla et al., 2011 and Anjum et al., 2003). Our results are in accordance with many researchers who reported that drought tolerant pearl millet genotypes accumulate higher proline than the susceptible genotypes (Mukhopadhyay et al., 2007 and Patil and Patil, 2007). From present results we conclude that proline accumulation plays adaptive roles in plant stress tolerance to oxidative stress and suggested that it is an evaluating parameter for selection of drought tolerant genotypes of the pearl millet (Giancarla et al., 2011).

\section{Glycine betaine}

Glycine betaine is major organic osmolytes that accumulate in a plant abundantly in response to dehydration stress. After the application PEG induced water-deficit stress 
to the plants the glycine betaine content was increased with increasing drought stress treatment $\mathrm{T}_{2}(6 \% \mathrm{PEG})$ to $\mathrm{T}_{3}(8 \% \mathrm{PEG})$ while this increment was higher in the tolerant genotype compared to the susceptible genotypes. The maximum glycine betaine accumulation was observed in genotype $\mathrm{J}$ 2454 (61.35 and $\left.72.59 \mu \mathrm{mol} . \mathrm{g}^{-1} \mathrm{Fw}\right)$ which was followed by the J-2340 (53.52 and 59.39 $\mu \mathrm{mol} . \mathrm{g}^{-1} \mathrm{FW}$ ) and ICMB-95444 (52.41 and $\left.58.43 \mu \mathrm{mol} . \mathrm{g}^{-1} \mathrm{FW}\right)$ during treatment $\mathrm{T}_{2}$ and $\mathrm{T}_{3}$ respectively. Higher accumulation of compatible osmolytes such as glycine betaine in leaves suggests that better osmotic regulation in these genotypes which may improve drought tolerance in pearl millet seedlings.

The lowest accumulation of the glycine betaine was found in genotype J-2549 (27.26 and $\left.34.39 \mu \mathrm{mol} . \mathrm{g}^{-1} \mathrm{Fw}\right)$ respectively which was followed by the ICMB-04111 (37.26 and $46.60 \mu \mathrm{mol} . \mathrm{g}^{-1} \mathrm{Fw}$ ) and J-2290 (36.55 and $\left.44.53 \mu \mathrm{mol} . \mathrm{g}^{-1} \mathrm{Fw}\right)$ during treatment $\mathrm{T}_{2}$ and $\mathrm{T}_{3}$ respectively (Table 5 ). Our results are supported by Ajithkumar and Panneerselvam, (2013) who reported that glycine betaine content was enhanced during increase in severity of drought stress during advancement of age in foxtail millet. A similar observation was made by Zhang et al., 2014 who reported the rapid increment in glycine betaine content at seedling stage under water-deficit stress in maize. The higher accumulation of GB indicates plants tolerance nature towards drought stress which ultimately provides greater protection to integrity of the cell membrane (Neto et al., 2009).

\section{Pearson correlation analysis}

Simple correlation coefficient analysis among the various physiological and biochemical parameters in pearl millet seedlings under well water control and PEG stress conditions shown in Table 6 . The results revealed a under PEG drought stress RWC significantly
$(\mathrm{P}<0.01)$ and positively associated with MSI and GB. While the proline and MDA were significantly and negatively correlated with RWC (Table 6). Similar findings were reported by Vijayalakshmi et al., (2012) in pearl millet genotypes. In contrast to the above results the MSI showed the negative correlation with proline and MDA previously reported by Choudhary et al., (2015). Proline showed the positive correlation with GB and MDA except RWC. The GB content showed the negative correlation with the MDA during analysis.

This analysis clearly showed that maintenance of higher membrane stability, photosynthetic machinery; plant water status and accumulation of compatible solutes play an important role in plants tolerance under drought conditions. RWC and MSI are known to be good indicators of stress-induced damages. The most widely measured indicator of membrane damage is MDA (Smirnoff, 1988). Considering the results in Table 6, which indicated negative correlation $(\mathrm{P}<0.01)$ among MDA and RWC, we have chosen J-2549 as susceptible and J-2454 as tolerant genotype for further pot trial. These genotypes have also been selected taking into consideration the fact that they are grown in the local region. Maraviya et al., (2011) carried out a similar screening of pearl millet genotypes for dehydration tolerance and grouped J-2454 as tolerant genotype.

\section{Acknowledgment}

The first author is thankful to the Department of Science and Technology, New Delhi for granting INSPIRE Fellowship for pursuing the full-time Ph.D. programme.

\section{References}

Addisie, Y., and Yemane, G. E. 2011. Response of pearl millet (Pennistetum glaucum) cultivars to post-flowering 
drought stress. Int. J. Plant Physiol. Biochem. 3: 150-154.

Ajithkumar, P., and Panneerselvam, R. 2013. Osmolyte accumulation, photosynthetic pigment and growth of Setaria italica (L.) P. Beauv. under drought stress. Asian Pac. J. Reprod. 2: 220-224.

Anjum, F., Yaseen, M., Rasool, E., Wahid, A. and Anjum, S. 2003. Water Stress in barley (Hordeum Vulgare L.) II. Effect on Chemical Composition and Chlorophyll Contents. Pak. J. Agri. Sci. 40: 45-49.

Aslam, M., Khan, I. A. and Saleem M. 2006. Assessment of water stress tolerance in different maize accessions at germination and early growth stage. Pak. J. Bot. 38: 1571-1579.

Bates, L. S., Waldren, R. P. and Teare, I. D. 1973. Rapid determination of free proline for water-stress studies. Plant Soil. 39: 205-207.

Blum, A., and Ebercon, A. 1981. Cell membrane stability as a Measure of drought and heat tolerance in wheat. Crop Sci. 21: 43-47.

Buchanan, B. B., Gruisem, W. and Jones, R. L. 2002. Responses to plant pathogens. In: Biochemistry and molecular biology of plants. American society of plant physiologists. Rockville, USA, pp. 1131-1142.

Choudhary, M., Manjhi, J. and Sinha, A. 2015. Effect of drought stress in various enzymes of Pennisetum glaucum. Int. J. Appl. Sci. Biotechnol. 3: 134-138.

Chugh, V., Kaur, N. and Gupta, A. K. 2011. Evaluation of oxidative stress tolerance in maize (Zea mays L.) seedlings in response to drought. Ind. J. Biochem. Biophys. 48: 47-53.

Geravandi, M., Farshadfar, E. and Kahrizi, D. 2011. Evaluation of some physiological traits as indicators of drought tolerance in bread wheat genotypes. Russ. J. Plant Physl. 58: 69-75.
Giancarla, V., Madosa, E., Sumalan, R., Ciulca, S., Nicoleta, B., Cerasela, P., Irina, P. and Iuliana, C. 2011. Proline accumulation in some barley genotypes exposed to drought. JHFB. 15: 48-54.

Gill, S., and Tuteja, N. 2010. Reactive oxygen species and antioxidant machinery in abiotic stress tolerance in crop plants. Plant physiol. Biochem. 48: 909-930.

Grieve, C. M. and Grattan, S. R. 1983. Rapid assay for determination of water soluble quaternary ammonium compounds. Plant Soil. 70: 303-307.

Heath, R. I., and Packer, L. 1968. Photoperoxidation in isolated chloroplast. Kinetics and stoichiometry of fatty acid peroxidation. Arch. Biochem. Biophys. 125: 189-198.

Khayatnezhad, M., Gholamin, R., JamaatieSomarin, S. H., Zabihi-Mahmoodabad, R. 2010. Effects of PEG stress on corn cultivars (Zea mays L.) at germination stage. World Appl. Sci. J. 11: 504-506.

Lata, C., Jha, S., Dixit, V., Sreenivasulu, N. and Prasad, M. 2010. Differential antioxidative responses to dehydration induced oxidative stress in core set of foxtail millet cultivars [Setaria italica (L.)]. Protoplasma. 248: 817-828.

Marviya, G. V., 2011. Biochemical and molecular aspects of moisture deficit stress tolerance in pearl millet (Pennisetum glaucum (L.) R. Br.) Genotypes. Ph.D. Thesis (Published) Junagadh Agricultural University, Junagadh.

Moussa, H. R., and Abdel-Aziz, S. M. 2008. Comparative response of drought tolerant and drought sensitive maize genotypes to water stress. Aust. J. Crop Sci. 1: 31-36.

Mukhopadhyay, R., Reddy, P. S., Pallela, R., Reddy, N. C., Rao, J. V., Hash, C. T. and Kavikishor, P. B. 2007. Differential responses of proline, ion accumulation and antioxidative enzyme activities in 
pearl millet [Pennisetum glaucum (L.) R. Br.] Lines differing in salt sensitivity. J. Plant Bioi. 34: 185-192.

Neto, F. O., Lobato, A. K. S., Costa, C. L., Maia, M. S., Filho, G. S., Alves, A. R., Brinez, B., Neves, K. B., Lopez, J. S. and Cruz, J. R. 2009. Nitrogen compounds and enzyme activities in sorghum induced to water deficit during three stages. Plant Soil Environ. 55: 238-244.

Patil, M. E., and Patil, S. D. 2007. Variations in different biochemical parameters of commercial pearl millet [Pennisetum glaucum (L.) R Br.] Hybrids under irrigated and terminal water stress conditions. AJES. 2: 77-80.

Reddy, A. R., Chaitanya, K. V. and Vivekanandan, M. 2004. Droughtinduced responses of photosynthesis and antioxidant metabolism in higher plants. J. Plant Physiol. 161: 11891202.

Sairam, R. K., and Srivastava, G. C. 2001. Water stress tolerance of wheat variations in hydrogen peroxide accumulation and antioxidant activity in tolerant and susceptible genotypes. $J$.
Agron. Crop sci. 186: 67-70.

Sammons, D. J., Peters, D. B. and Hymowitz, T. 1978. Screening soybeans for drought resistance: Growth chamber procedure. Crop Sci., 18: 1050-1055.

Smart, E. R., and Bingham, G. E. 1974. Rapid estimates of relative water content. Plant Physiol. 53: 258-260.

Turner, N. C., 1997. Further progress in crop water relations. Adv. Agron., 58: 293338.

Vijayalakshmi, T., Varalaxmi, Y., Jainender, S., Yadav S. K., Vanaja M., Jyothilakshmi, N. and Maheswari, M. 2012. Physiological and biochemical basis of water-deficit Stress tolerance in pearl millet hybrid and parents. Am. J. Plant Sci. 3: 1730-1740.

Zhang, L. X., Lai, J. H., Liang, Z. S. and Ashraf, M. 2014. Interactive effects of sudden and gradual drought stress and foliar applied glycine betaine on growth, water relations, osmolyte accumulation and antioxidant defense system in two maize cultivars differing in drought tolerance. J. Agro. Crop Sci. 200: 0931- 2250.

\section{How to cite this article:}

Shubham B. Deshmukh and Mandavia, M.K. 2017. Effects of PEG-6000 Induced Water Deficit Stress on Physiological and Biochemical Characteristics of Pearl Millet Seedlings. Int.J.Curr.Microbiol.App.Sci. 6(10): 1581-1591. doi: https://doi.org/10.20546/ijcmas.2017.610.190 